\title{
КУЛЬТУРНОЕ НАСЛЕДИЕ
}

\author{
УДК 94:(059.3)*2+793(571.1)',1920/1930',
}

DOI: $10.17223 / 22220836 / 24 / 14$

\section{П.Е. Азарова}

\section{НАСТОЛЬНЫЙ КАЛЕНДАРЬ КАК АТРИБУТ ПРАЗДНИКОВ В ЗАПАДНОЙ СИБИРИ В 1920-1930-х гГ.}

\begin{abstract}
В статье рассматривается место и значение календарей в организачии праздничного времени. Характеризуется структура настольных календарей, выявляются основные виды и типы календарных изданий. Показаны изменения в оформлении и содержании праздничных календарей как отражение перемен в общественно-политическом устройстве и жизненном укладе населения в первые десятилетия советской власти. Прослеживается утверждение новых сочиокультурных приоритетов через посредство календарной сетки, закрепление памятных и праздничных дат, связанных с событиями революиии и сочиалистического строительства.

Ключевые слова: календарь, праздник, праздничные атрибуты, праздничнье технологии, памятные события.
\end{abstract}

Изучение истории праздника в контексте актуализации культурного наследия требует рассмотрения и осмысления места и роли праздничных атрибутов, в их числе - календарей. С давних времен печатные издания календарей включали обязательный перечень месяцев, чисел, дней недели, а также и праздников. Они представляли не только организованную повседневность, но и формировали празднично-памятное пространство, посредством провозглашения различных торжеств, памятных событий. В данной публикации рассматриваются настольные календари, распространяемые на территории Западной Сибири в 1920-1930-х гг.

Структура настольных календарей XIX-XX вв. была практически универсальной, она включала несколько информационных блоков, в их числе сведения общественно-политического характера и календарные сетки. В первом информационном блоке, как правило, содержались сведения о государственном руководстве. Сначала это были рисунки, фотографии императорской семьи и министров царского правительства, а после 1917 г. руководителей Коммунистической партии и советского правительства. В календарях 1920-х гг. данный блок представляет целую плеяду политических деятелей: В.И. Ленин, И.В. Сталин, М.И. Калинин, А.И. Рыков и др. В изданиях 1930-х гг. остались только Ленин и Сталин [1. С. 25; 2. С. 31; 3. С. 3; 4. С. 37; 5. С. 81]. В календарях публиковались фотографические портреты партийно-государственных деятелей, они сопровождались краткими пояснениями о месте и значении тех или иных лиц в государственной иерархии.

Вслед за первым следовал собственно календарный блок, представленный в виде табеля на каждый месяц года. Нужно заметить, что русские календари имперского периода опирались на юлианскую систему летоисчисле- 
ния, включали указания на знаменательные даты, по большей части связанные с историей царского дома Романовых, и на православные события и праздники. После революции, когда в феврале 1918 г. в России произошел переход от юлианского к григорианскому календарю, началась переработка внутренней структуры календарей. Разрабатывались проекты о новом летоисчислении, например, от начала Октябрьской революции [6. С. 14]. Предлагалось переименовать все месяцы, чтобы в новых названиях присутствовали имена и события революции: январь - месяц Ленина, февраль - месяц Маркса; март - месяц Революции; апрель - месяц Свердлова; май - месяц Мая; июнь - месяц Советской конституции; июль - месяц жатвы; август - месяц мира; сентябрь - месяц Коминтерна; октябрь - месяц Энгельса; ноябрь - месяц Великой революции; декабрь - месяц Сталина [4. С. 45-47]. Нельзя не отметить проект о переходе на непрерывную пятидневную неделю. Авторы проекта предлагали с помощью цветных квадратов обозначать дни недели: первый - День Коммуны, второй - День Маркса, третий - День Энгельса, четвертый - День Ленина, пятый - День Сталина [7. С. 5; 8. С. 3; 9. С. 27]. Разрабатывались проекты шестидневной недели с отказом от традиционных названий дней недели, с приданием им порядковых номеров (первый, второй, третий и т. д.). Частично такой порядковый календарь использовался в период с 1 декабря 1931 г. по 26 июня 1940 г. [10. С. 3] Все же подобные проекты не прижились, и в 1940 г. в Советской России произошел возврат к семидневной рабочей неделе с традиционными названиями дней недели - понедельник, вторник и т. д. [11. С. 1].

Изменения в календарной сетке отражали перемены в жизненном укладе населения, регламентировали повседневность, в частности сочетание и чередование рабочих и праздничных/нерабочих дней. При этом количество выходных и праздничных дней динамично менялось, находясь в зависимости от политической ситуации в стране. До середины 1920-х гг. органами советской власти допускались традиционные православные праздники, и хотя эти праздничные дни не вводились в официальные календари, они все же были нерабочими. Но в дальнейшем, хотя и не резко, началось обесценивание православных праздников и Нового года и исчезновение их из числа нерабочих дней. Одновременно в рассматриваемых календарях происходило утверждение приоритета событий революционного движения и свершений советской эпохи.

Явные перемены в праздничном календаре наблюдаются в 1930-х гг. Прежде всего произошло сокращение общего количества официальных праздничных дней. Насчитывалось всего шесть нерабочих дней: 22 января - Память Ленина, 1 и 2 мая - День солидарности трудящихся, 7 и 8 ноября - Великая Октябрьская социалистическая революция, 5 декабря - День советской Конституции. Многие календарные даты, такие как антивоенный день 1 августа, День Парижской коммуны 18 марта, сохраняли за собой статус государственного праздника, но с середины 1920-х гг. отмечались в рабочие дни. Календари содержали даты из истории революционного движения в России, обязательными были даты памяти: дни рождения и смерти деятелей Советского государства и зарубежного коммунистического движения. Если для императорской России были характерны в основном дни памяти и годовщины, то для Советской России довоенного периода помимо перечисленных можно выделить еще и полугодовщины [12. С. 31-54; 13. C. $41-66 ; 14$. C. 52-74]. 
В дни памяти, как правило, вспоминались определенные события и деятели революционного движения, борьбы за новое социалистическое общество. Годовщина представляла особый вид памяти о государственно значимом событии, была призвана консолидировать социум перед общими врагами и мотивировать установку на защиту Родины. При этом положенные в основу события человеческие жертвы, поражение в сражении или восстании должны были демонстрировать ненапрасность жертв, торжество новой жизни (Кровавое воскресенье, гибель бакинских комиссаров и др.). Датой годовщины считался день их учреждения, но периодичность проведения годовщин могла быть различной, в зависимости от масштабности события или личности. День памяти В.И. Ленина, совпадавший с днем жертв Кровавого воскресенья - 22 января, отмечался ежегодно, другие годовщины отмечались раз в пятилетие. Некоторым событиям придавалось настолько важное значение, что помимо годовщин отмечались и полугодовщины. Но все-таки полугодовые торжества не носили ежегодный характер празднования, отмечались несколько раз за десятилетие, а затем исчезали из календаря торжеств, соответствуя политическим маневрам Советского государства.

Третий блок настольных календарей включал небольшие очерки о важнейших событиях советской истории и персоналии советских и революционных деятелей. Как правило, они располагались после календарной сетки на месяц и освещали исторические события текущего месяца, например крестьянское восстание под руководством Емельяна Пугачева, Кровавое воскресенье, восстание декабристов. Особое внимание уделялось партийнополитическим событиям - создание и деятельность Коммунистической партии в России, подготовка и ход Великой Октябрьской социалистической революции, основание Коммунистического интернационала и др.

По содержанию и характеру информации настольные календари 1920 1930-х гг. можно подразделить на общегосударственные и специальные, в частности антирелигиозные, сельскохозяйственные, детские. Такие специальные, или профилированные, календари были ориентированы на отдельные социальные слои или группы людей, отражали значимость для партийногосударственной пропаганды конкретных субкультур, в работе с которыми использовались соответствующие календарные и праздничные даты.

Антирелигиозные календари освещали даты и события, связанные с разоблачением религии и падением авторитета церкви на протяжении всей истории человечества. В сопроводительных к календарным сеткам статьях приводились факты и открытия в естественно-научном мире, провозглашался лозунг «Борьба против религии есть борьба за коммунизм». Прилагались справки о православных торжествах - Рождестве, Пасхе, им давалось исключительно негативное толкование. Религиозная тематика присутствовала в 1920-х гг. в сельскохозяйственных календарях, в них революционный и церковный календари располагались на страницах буквально рядом [1. С. 39; 12. С. 33-46; 15. С. 59-74; 14. С. 12-31]. Резко изменился характер календарей в 1930-е гг., они отличались насыщенной сатирической формой подачи информации в отношении церкви, включали сказки, пословицы, стихотворения, частушки антицерковной направленности [13. С. 24-43; 2. С. 15-41; 5. С. 35-46]. 
Настольные календари первых десятилетий советской власти служили одним из важнейших инструментов праздничных технологий в стране в целом и в Западной Сибири в частности. В целом ряде случаев они издавались и использовались как ориентир в организации и проведении праздников, поэтому могут рассматриваться как обязательный атрибут досуговой и праздничной культуры. Разнообразная, научно значимая информация о праздниках и других общественных явлениях обеспечивает возможность и необходимость музеефикации календарей, сохранения и использования их в экспозиционной и культурно-образовательной работе.

\section{Литература}

1. Календарь антирелигиозника на 1939 г. М. : Соцэкгиз, 1938. 400 с.

2. Настольный крестьянский календарь на 1927 г. М. : Соцэкгиз, 1926. 450 с.

3. Конович А.А. Театрализованные праздники и обряды в СССР. М. : Высш. шк., 1990. 208 с.

4. Сельскохозяйственный настольный календарь на 1926 г. М. : Изд. Крестьянской газеты, 1925. $82 \mathrm{c}$. $250 \mathrm{c}$.

5. Сибирский настольный календарь на 1925 г. Новониколаевск : СИБКРАЙИЗДАТ, 1924.

6. Дубнер П.М. Советский календарь // Огонек. 1929. № 40. С. 14-21.

7. Викторов Ю. Нужен почин // Изв. ЦИК Союза ССР и ВЦИК Советов. 1929. № 98. С. 5.

8. Мотивы за пятидневку (обзор читательских писем) // Изв. ЦИК Союза ССР и ВЦИК Советов. 1929. №199. С. 3.

9. Кремлев-Свэн И.Л. Две беседы о непрерывной неделе. М. : Гос. политиздат., 1930. 100 с.

10. Историко-революиионный календарь 1940 г. М. : Соцэкгиз, 1939. 687c.

11. Указ Президиума Верховного Совета СССР от 26 июня 1940 г. «О переходе на восьмичасовой рабочий день, на семидневную рабочую неделю и о запрещении самовольного ухода рабочих и служащих с предприятий и учреждений» // Ведомости Верховного Совета Союза Советских Социалистических Республик. 1940. № 20. С. 1.

12. Календарь антирелигиозника на 1941 год. М. : ОГИЗ, Государственное антирелигиозное изд-во, $1940.480 \mathrm{c}$.

13. Календарь. Воинствующий безбожник. 1932 г. М. : ОГИЗ, Государственное антирелигиозное издательство, 1931. 400с.

14. Сибирский настольный сельскохозяйственный и промышленный календарь на 1925. Новониколаевск : СИБКРАЙИЗДАТ, 1925. 300 с.

15. Календарь на 1933 год. Новосибирск : ОГИЗ, 1933. 750 с.

Azarova Polina E. Tomsk State University (Tomsk, Russian Federation)

E-mail: azarova.p@mail.ru

Tomsk State University Journal of Cultural Studies and Art History, 2016, (4) 24; 134-138 pp. DOI: $10.17223 / 22220836 / 24 / 14$

THE DESK CALENDAR AS AN ATTRIBUTE OF WEST SIBERIAN HOLIDAYS IN 1920-30-s

Key words: calendar, holiday, holiday attributes, holiday technologies, commemorations.

This article is devoted to the little-known attributes of city holidays; it studies desk calendars, common in West Siberia in 1920-1930-s. It is showed that the structure of the desktop calendars was almost universal during the 19th and 20th centuries. As a rule, it includes details of the socio-political nature and the calendar grid.

There were portraits of the Communist Party and the Soviet State leaders - Lenin, Stalin, Kalinin, Rykov and others in the Calendars, published after the Revolution of 1917. In the calendars of 1930-s only Lenin and Stalin' portraits remained. These images formed the first block of calendars. The second part of the calendars included the actual calendar block; it was a table for each month of the year. Calendar grid reflected those changes, what took place in the lifestyle of the population, and in the system of chronology. Suggested, for example, to rename the months and reflect the new revolutionary reality in new names. Therefore, it was proposed to call January as month of Lenin, February - month 
of Marx etc. Renaming of days of the week were planned: Monday would be a day of Commune, Tuesday - day of Marx. Still all of those proposals had failed.

As to the number of weekends and holidays in the calendar it was dynamically changed, and that changing showed its depending on the socio-political situation in the country. During 1920-s there were marked not only Soviet holidays, but also religious. Although they were not present in the calendars. In the 1930-s, the number of official holidays was reduced to six days a year: they were January 22 (Lenin's Memory), May 1 and 2 (Labor Day), November 7 and 8 (Great October Socialist revolution), December 5 (Day of the Soviet Constitution). All of other holidays were celebrated in working time.

The third block of desktop calendars included essays on major events of Soviet history and of Soviet and revolutionary leaders. As a rule, that publications were confined to historical dates of the current month. The content and nature of the information allows you to subdivide the desk calendars of 1920-1930-s on national and special. Special calendars included anti-religious, agricultural, baby issues. Special calendars information was designed for different social groups. Such calendars allowed Party-and-State agencies to use the calendar and holidays dates for the sake of extending its influence among the population.

The desk calendars served as one of the most important tools of holiday technologies. They were used in the organization and carrying out of holidays in West Siberia, and thus may be considered as an obligatory attribute of leisure and festive culture. A variety of information about the holidays in calendars provides the opportunity of transformation of the calendars into museum subjects and using them in museum studies.

\section{References}

1. Fedoseev, P.N. (ed.) (1938) Kalendar' antireligioznika na $1939 \mathrm{~g}$. [The calendar of an antireligious fighter for 1939]. Moscow: Sotsekgiz.

2. Uritskiy, S.B. (ed.) (1926) Nastol'nyy krest'yanskiy kalendar' na 1927 g. [Peasants' desk calendar for 1927]. Moscow: Sotsekgiz.

3. Konovich, A.A. (1990) Teatralizovannye prazdniki i obryady v SSSR [Theatrical festivals and rituals in the USSR]. Moscow: Vysshaya shkola.

4. Gurov, P.Ya. (ed.) (1925) Sel'skokhozyaystvennyy nastol'nyy kalendar' na 1926 g. [An agricultural desk calendar for 1926]. Moscow: Krest'yanskaya gazeta.

5. Anon. (1924) Sibirskiy nastol'nyy kalendar' na $1925 \mathrm{~g}$. [Siberian desktop calendar for 1925]. Novonikolaevsk: SIBKRAYIZDAT.

6. Dubner, P.M. (1929) Sovetskiy kalendar' [The Soviet calendar]. Ogonek. 40. pp. 14-21.

7. Viktorov, Yu. (1929) Nuzhen pochin [We need initiative]. Izv. TsIK Soyuza SSR i VTsIK Sovetov. 98. pp. 5.

8. The Central Executive Committee of the Soviet Union. (1929) Motivy za pyatidnevku (obzor chitatel'skikh pisem) [Motives for a five-day work week (a review of readers' letters)]. Izv. TsIK Soyuza SSR i VTsIK Sovetov. 199. pp. 3.

9. Kremlev-Sven, I.L. (1930) Dve besedy o nepreryvnoy needle [Two talks about the continuous week]. Moscow: Gospolitizdat.

10. Lebedev, V., Bushuev, S. \& Eggert, Z. (eds) (1939) Istoriko-revolyutsionnyy kalendar' 1940 g. [Historical and revolutionary calendar for 1940]. Moscow: Sotsekgiz.

11. The Supreme Soviet of the Soviet Union. (1940) Ukaz Prezidiuma Verkhovnogo Soveta SSSR ot 26 iyunya 1940 g. "O perekhode na vos'michasovoy rabochiy den', na semidnevnuyu rabochuyu nedelyu i o zapreshchenii samovol'nogo ukhoda rabochikh i sluzhashchikh s predpriyatiy i uchrezhdeniy" [Decree of the Supreme Soviet of the USSR of June 26, 1940 "On the transition to the eight-hour work day, seven-day work week and the prohibition of unauthorized departure of workers and employees from enterprises and institutions"]. Vedomosti Verkhovnogo Soveta Soyuza Sovetskikh Sotsialisticheskikh Respublik. 20. pp. 1.

12. Mikhnevich, D.E. (1940) Kalendar' antireligioznika na 1941 god [The calendar of the antireligious fighter for 1941]. Moscow: OGIZ.

13. Anon. (1931) Kalendar': Voinstvuyushchiy bezbozhnik. 1932 g. [Calendar: Militant atheist for 1932]. Moscow: OGIZ.

14. Anson, L. \& Basov, M. (eds) (1925) Sibirskiy nastol'nyy sel'skokhozyaystvennyy i promyshlennyy kalendar' na 1925 [Siberian agricultural and industrial desktop calendar for 1925]. Novonikolaevsk: SIBKRAYIZDAT.

15. Anon. (1933) Kalendar' na 1933 god [Calendar for 1933]. Novosibirsk: OGIZ. 